After the Greenland expedition an attempt was made to obtain a second set of control readings in the U.K., but unexpectedly high levels were obtained-in some instances as high as those from the ice-cap. Twelve observations were made on random days while the subjects were at their normal occupations; $\mathrm{G}$ is an author and housewife, $\mathrm{H}$ a company secretary, F a clinical lecturer, and $\mathrm{E}$ a school-teacher. Thus all the subjects held responsible and to a certain extent competitive jobs, and it is apparent that such occupations may result in more stress and adrenal cortical stimulation than has been hitherto recognized. It is of considerable interest that a university lecturer had a higher output of 17-OHCS during 12 random days of the busy autumn term period than at any time during a ski traverse of a 400 -miles $(640-\mathrm{km}$.) ice-cap, the average levels being $178 \%$ and $140 \%$ respectively above holiday controls. These observations accord with the fact that people in higher socio-economic groups tend to have higher steroid outputs-see discussions by Barnicot and Wolffson (1952), Politzer and Tucker (1958), and Edozien (1960). They also accord with my own observations that food-gathering Amerindians in the Surinam rain forest have much lower 17OHCS outputs than medical students in Glasgow, even when their smaller body mass is considered (Simpson, 1965a). However, it is probably too early to conclude that there is adrenal hyperfunction in affluent westerners; the results might merely indicate alteration in thyroid function and faster steroid turnover. More work has to be done, especially since the question is highly relevant in the aetiology of stress diseases.

It has often been presumed that stress is a threat of some sort to the organism and therefore something to be avoided. Is this so ? Some years ago Pugh (1954) showed that skiers at a resort were stressed in the evening, and he pointed out the obvious beneficial effects of these holidays. After a month of stress on our Greenland crossing we went straight on to complete a $250-$ mile $(400-\mathrm{km}$.) canoe journey up the coast, a journey in every way more dangerous than the sledging. Obviously the journey had not caused any marked deterioration in our physical condition. Equally, however, the leader of the long Antarctic sledging journey, who was stressed merely by camping in the field, was stressed sufficiently to resign the leadership. It would seem, therefore, that the difference between beneficial stress and that causing mental changes is a matter of degree and duration.

\section{Summary}

A field investigation of human stress situations in polar regions has been carried out. The blood eosinophil level and urinary 17-hydroxycorticosteroid output were used as indices of adrenal activity.

Men living in a British Antarctic sledging base had a fairly stable venous blood eosinophil count. Significant deviations from this level occurred when disturbing radio signals were received or when departure on a sledge journey was imminent. While in the field there was a profound eosinopenia in the evening after travelling and usually an extension of this to the following morning; in one instance the chronic eosinopenia lasted 85 days. Similarly in a party skiing 400 miles $(640 \mathrm{~km}$.) across the Greenland ice-cap there was a raised output of 17-OHCS in the urine for the full 40 days of the crossing from coast to coast. No adaptation to the stress took place.

The question of whether people in the higher socio-economic group have high $17-\mathrm{OHCS}$ excretion rates is discussed.

\section{BIBLIOGRAPHY}

Appleby, J. I., Gibson, G., Norymberski, J. K., and Stubbs, R. D. (1955)

Biochem. F., 60, 453.

Berkson, J., Magath, T. B., and Hurn, M. (1940). Amer. F. Physioi. 128. 309 .

Bliss, E. L., Sandberg, A. A., Nelson, D. H., and Eik-Nes, K. (1953). F. clin. Invest., 32, 818.

Doe, R. P., Flink, E. B., and Flint, M. G. (1954). 7. clin. Endocr., 14,

Edozien, J. C. (1960). Lancet, 1, 258.

Frost, J. W., Dryer, R. L., and Kohistaedt, K. G. (1951). 9. Lab. clin Med., 38, 523 .

Gabrilove, J. L. (1950). J. clin. Endocr., 10, 637.

Humphreys, R. J., and Raab, W. (1950). Proc. Soc. exp. Biol. (N.Y.) 74,302 .

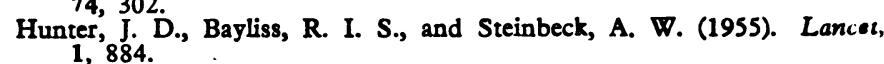

Kinloch, J. D. (1959). Brit. J. Nutr., 13, 85.

Peterson, R. E. (1957). ¥. clin. Endocr., 17, 1150.

Politzer, W. M., and Tucker, B. (1958). Lancet, 2, 778

Pugh, L. G. C. E. (1954). Proc. Nutr. Soc., 13, 60.

Pugh, L. G. C. E. (1954). Proc. Nu.

Simpson, H. Writ. (1959). M.̈. 1, Thesis, Edinburgh Undveralty.

(1965a). F. Endocr., 32, 179.

(1965b). Ph.D. Thesis, Glasgow University.

- (1965c). Med. Wld News, 6, No. 45, p. 44

Thorn, G. W (1953). Trans. Ass. Amer. Phycns, 66, 48

Forsham. P. H., Prunty, F. T. G., and Hills, A. G. (1948). 9. Amer. Med. Ass. 137., 1005.

Vogt, M. (1944). F. Physiol. (Lond.), 103, 317.

\title{
Behaviour Disorders and Pattern of Crime among XYY Males Identified at a Maximum Security Hospital
}

\author{
W. H. PRICE,* M.B., B.SC., M.R.C.P.ED. ; P. B. WHATMORE, $†$ M.B., LL.B., D.P.M.
}

Brit. med. F., 1967, 1, 533-536

In 1965 Jacobs et al. published the preliminary results of a chromosome survey of men who were patients at the State Hospital, Carstairs, and the final report on this is at present being prepared. The survey was undertaken to test the idea that men with an XYY sex chromosome complement might be unusually frequent among those in the special hospitals in England and in the State Hospital in Scotland. This idea stemmed from the finding by Casey et al. (1966b) of a relatively high frequency of males with an XXYY complement in Moss Side and Rampton and their known low frequency in hospitals for the mentally subnormal (Maclean et al., 1962) and among the newborn (Maclean et al., 1964).

Altogether nine XYY males were found, a frequency of nearly $3 \%$, and these findings have been substantiated by recent work at Moss Side, Rampton, and Broadmoor by Casey et al. (1966a). In a previous publication Price et al. (1966) reported the lack of evidence for abnormal physical development from examination of the nine XYY males at Carstairs. This paper reports the results of a detailed assessment of the behaviour characteristics of these men.

\section{The Hospital}

The State Hospital, Carstairs, is an institution provided by the Secretary of State for Scotland in terms of Part VII of the

\footnotetext{
- M.R.C. Clinical Effects of Radiation Research Unit, Western General Hospital, Edinburgh 4.

† State Hospital, Carstairs, Lanarkshire.
} 
Mental Health (Scotland) Act 1960 for persons subject to detention under the Act who require treatment in conditions of special security on account of their dangerous, violent, or criminal propensities. One wing of the hospital was opened in 1948 to receive mentally subnormal patients, and in 1957 additional new buildings were completed to accommodate patients suffering from mental illness.

Today the hospital is divided into the East wing, for mentally subnormal patients, and the West wing, for those patients suffering from mental illness. The majority of patients in the West wing are of average or above average intelligence, but segregation of the patients based on intelligence is not strictly observed, as other factors have to be taken into account.

In assessing the features of the XYY males found in the State Hospital it is important to have some knowledge of how patients may be admitted to this hospital. Up until 1962 mental defectives could be admitted by court order, on transfer from mental defective hospitals, and from prison. Mentally ill patients could be admitted only by court order or on transfer from prison. In 1962 the Mental Health (Scotland) Act 1960 came into operation and patients are now admitted by one or other of the following ways: (a) on committal by the courts; (b) from penal institutions where mental illness or mental subnormality is diagnosed during the course of a prison sentence ; and $(c)$ from other mental hospitals and hospitals for the mentally subnormal, whether or not they were admitted there on court committal.

Thus patients can be admitted who have not committed criminal acts. It should also be said that this hospital is not part of the Prison Service.

\section{Patients}

At the time of the chromosome survey there were 342 male patients at the hospital, 203 in the East wing and 139 in the West wing. Of the total of 342 patients 249 were admitted from the courts and 93 were transferred from other institutions. All but 10 had criminal records.

These patients can be placed in one of four categories of mental disorder (Table I).

TABt. I.-Diagnostic Categories of Male Patients at the State Hospital,

\begin{tabular}{c|c|c|c|c|c}
\hline Diagnosis & $\begin{array}{c}\text { Brain } \\
\text { Damage }\end{array}$ & Epilepsy & Psychosis & \multicolumn{2}{|c|}{$\begin{array}{c}\text { Carstairs } \\
\text { Severe Personality } \\
\text { Disorders of } \\
\text { Undetermined Cause }\end{array}$} \\
\hline $\begin{array}{c}\text { Normal } \\
\text { Intelligence }\end{array}$ & $\begin{array}{c}\text { Subnormal } \\
\text { Intelligence }\end{array}$ \\
\hline $\begin{array}{c}\text { All 342 male patients } \\
9 \text { XYY patients }\end{array}$ & $-\cdots$ & $\underline{41}$ & $\underline{4}$ & 86 & 167 \\
\hline
\end{tabular}

Brain Damage.-Four patients were known to have suffered from brain damage. The causes of the brain damage were trauma, cerebrovascular syphilis, and severe meningitis.

Epilepsy.-Twenty patients suffered from major seizures. Twenty-one others suffered from focal attacks or temporal lobe epilepsy. All the patients in this group displayed psychiatric manifestations of epilepsy, often leading to violence during the prodromal period, during the attack, or as a postepileptic phenomenon. Some were also mentally subnormal.

Psychosis.-Forty-four patients suffered from schizophrenia or affective psychosis, some being of average intelligence and some mentally subnormal.

Severe Personality Disorder of Undetermined Origin.-This was the largest category and totalled 253 patients. It was composed mainly of sexual deviants, chronic alcoholics, fire raisers, aggressive psychopaths, and inadequate psychopaths. In this category there were 86 patients who were of average or above average intelligence, and 167 patients who were mentally subnormal.

It was possible to undertake chromosome studies in 315 of the 342 men, 196 from the East wing and 119 from the West wing. Seven XYY's were found in the East wing, six of whom were mentally subnormal, while the seventh was of average intelligence $(I \cdot Q=93)$. The remaining two XYY's were found in the West wing. One had an I.Q of 60 , the other being of average intelligence. Six of these nine men were admitted to the hospital before 1957 and three since that date.

In investigating the XYY males their behaviour was compared with that of 18 male patients randomly selected from the list of men classified as having a severe personality disorder of undetermined cause whether mentally subnormal or not. Seventeen of these were known to have an XY complement, while the remaining control had not been willing to provide a blood sample for chromosome study. Of these 18 patients six were admitted before 1957 and 12 since that date.

The XYY males and the controls had been known to one of us (P. B. W.) for two and a half years, and knowledge gained during this period has been used in our assessment. Additional information has been obtained from further interviews with the XYY patients, from interviews with their relatives, and from the scrutiny of hospital records.

\section{Results}

\section{Clinical Picture}

All nine XYY patients suffer from a severe degree of personality disorder. There is no known history of brain damage, epilepsy, or psychosis to account for this. Seven of the nine are mentally subnormal with I.Q.s ranging between 60 and 80 .

Their personalities show extreme instability and irresponsibility, and in their criminal behaviour these men do not appear to have considered any but the most immediate consequences of their actions. They have few constructive aims for the future and the plans they make are generally unrealistic. In their emotional responses they show very little depth of affection for others and their capacity for understanding is more limited than would be expected from their level of intelligence. They display an impaired awareness of their environment, which appears, at least partly, to account for their inability to respond appropriately to the ordinary requirements of life. Their greatest difficulty in social adjustment, however, arises from emotional instability, combined with an incapacity to tolerate the mildest frustration. They adjust well to the environment of this hospital and only very rarely do they display any violent reactions.

In comparison with the XYY males the control patients are more openly hostile, and violently aggressive outbursts are more common. In most other respects, however, their personalities are very similar. Ten of the 18 were mentally subnormal with I.Q.s ranging between 60 and 80 .

\section{Criminal Records}

Three of the nine XYY males had been convicted before the age of 10 years and the mean age at first conviction for all was 13.1 years. None of the 18 controls had been convicted before the age of 10 years and the mean age at first conviction in this group was 18 years. The difference in the means $($ S.E. $=2.33$ ) is significant at the $5 \%$ level. Even before their first convictions at least five of the nine XYY males had been in trouble with education authorities and the police on account of minor offences or persistent truancy from school.

The penal records of the two groups of patients are shown in Tables II and III and analyses of the data in Tables IV-VI. There is very little difference between the XYY males and the $\mathrm{XY}$ controls in respect of crimes against property (Table IV). There is, however, a striking difference in the number of convictions for crimes against the person (Table V). Only 
TABLE II.-Penal Records of 9 XYY Males

\begin{tabular}{|c|c|c|c|c|c|c|c|c|c|c|c|c|c|}
\hline \multirow{3}{*}{ Case No. } & \multirow{3}{*}{$\begin{array}{l}\text { Present } \\
\text { Age }\end{array}$} & \multicolumn{3}{|c|}{ Age at } & \multicolumn{8}{|c|}{ Number of Convictions } & \multirow{3}{*}{$\begin{array}{l}\text { Previous Places } \\
\text { of Detention }\end{array}$} \\
\hline & & \multirow{2}{*}{$\begin{array}{c}\text { First } \\
\text { Court } \\
\text { Convic- } \\
\text { tion }\end{array}$} & \multirow{2}{*}{$\mid \begin{array}{c}\text { First } \\
\text { Court } \\
\text { Commit- } \\
\text { tal to } \\
\text { Hospital* }\end{array}$} & \multirow{2}{*}{$\begin{array}{l}\text { Admis- } \\
\text { sion to } \\
\text { State } \\
\text { Hospital }\end{array}$} & \multicolumn{3}{|c|}{ Crimes Against the Person } & \multicolumn{3}{|c|}{ Crimes Against Properties } & \multirow[b]{2}{*}{ Fraud } & \multirow[b]{2}{*}{$\begin{array}{c}\text { Other } \\
\text { Offences }\end{array}$} & \\
\hline & & & & & Murder & Assault & $\begin{array}{c}\text { Serious } \\
\text { Sex } \\
\text { Offences }\end{array}$ & Theft & $\begin{array}{l}\text { H.B. } \\
\text { and } \\
\text { O.L.P.† }\end{array}$ & Others & & & \\
\hline $\begin{array}{l}134 / 65 \\
141 / 65 \\
142 / 65 \\
150 / 65 \\
120 / 65 \\
152 / 65 \\
123 / 65\end{array}$ & $\begin{array}{l}32 \\
29 \\
35 \\
23 \\
32 \\
29 \\
40\end{array}$ & $\begin{array}{r}18 \\
15 \\
9 \\
14 \\
10 \\
21 \\
8\end{array}$ & $\begin{array}{r}\overline{15} \\
9 \\
14 \\
\overline{-} \\
10\end{array}$ & $\begin{array}{l}18 \\
19 \\
18 \\
18 \\
17 \\
25 \\
30\end{array}$ & $\begin{array}{l}\frac{-}{1} \\
= \\
=\end{array}$ & $\begin{array}{l}= \\
\bar{z} \\
=\end{array}$ & $\frac{1}{\frac{1}{4}}$ & $\begin{array}{r}-1 \\
3 \\
6 \\
2 \\
6\end{array}$ & $\begin{array}{r}-1 \\
29 \\
4 \\
4 \\
3\end{array}$ & $\frac{-}{5}$ & $\begin{array}{l}\frac{-}{3} \\
= \\
=\end{array}$ & $\begin{array}{l}= \\
= \\
=\end{array}$ & $\begin{array}{l}\text { Approved school } \\
\text { Approved school, Borstal } \\
\text { Prison } \\
\text { Approved school, Borstal. }\end{array}$ \\
\hline $\begin{array}{l}122 / 65 \\
132 / 65\end{array}$ & $\begin{array}{l}33 \\
18\end{array}$ & $\begin{array}{r}9 \\
14\end{array}$ & $\begin{array}{l}11 \\
14\end{array}$ & $\begin{array}{l}24 \\
15\end{array}$ & $=$ & $\overline{1}$ & - & $\underline{7}$ & $\begin{array}{l}7 \\
3\end{array}$ & $\overline{1}$ & 二 & 二 & $\begin{array}{l}\text { prison } \\
\text { Approved school }\end{array}$ \\
\hline
\end{tabular}

* Hospital for mental defectives.
t Housebreaking and opening of lock-fast places.

TABLe III.-Penal Records of 18 Control Patients

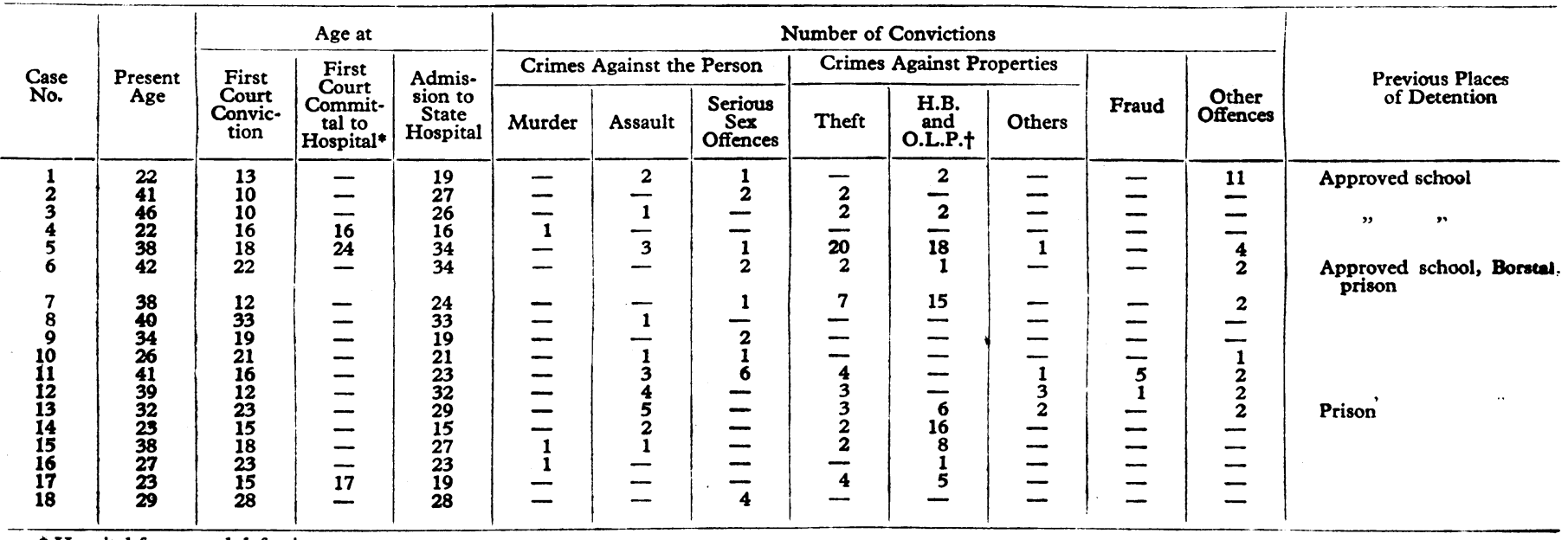

- Hospital for mental defectives.

+ Housebreaking and opening of lock-fast places.

four of the nine XYY males had been convicted of this class of crime, compared with 17 out of the 18 controls.

Among the four XYY patients one had been convicted of murder, and two had convictions for common assault and two for sexual offences against young children. By contrast, among the 17 controls, three had been convicted of murder, and nine had convictions for common assault and nine for serious sexual offences. The XYY male convicted of murder was apprehended

\begin{tabular}{|c|c|c|c|c|c|}
\hline \multirow{2}{*}{ Category } & \multirow{2}{*}{$\begin{array}{l}\text { Total } \\
\text { Men }\end{array}$} & \multicolumn{2}{|c|}{ Total Convictions } & \multicolumn{2}{|c|}{$\begin{array}{c}\text { Mean No. of Conviction } \\
\text { per Man }\end{array}$} \\
\hline & & $\begin{array}{l}\text { Against } \\
\text { Persons }\end{array}$ & $\begin{array}{c}\text { Against } \\
\text { Property }\end{array}$ & $\begin{array}{l}\text { Against } \\
\text { Persons }\end{array}$ & $\begin{array}{c}\text { Against } \\
\text { Property }\end{array}$ \\
\hline $\begin{array}{l}\mathbf{X Y Y} \\
\mathbf{X Y}\end{array}$ & $\begin{array}{r}9 \\
18\end{array}$ & $\begin{array}{r}8 \\
46\end{array}$ & $\begin{array}{r}81 \\
132\end{array}$ & $\begin{array}{l}0 \cdot 9 \\
2 \cdot 6\end{array}$ & $\begin{array}{l}9 \cdot 0 \\
7 \cdot 7\end{array}$ \\
\hline
\end{tabular}

TABLB V.-Records of Convictions Against Person (In Detait)

\begin{tabular}{|c|c|c|c|c|c|c|c|}
\hline \multirow[b]{2}{*}{ Category } & \multirow{2}{*}{$\begin{array}{l}\text { Total } \\
\text { Men }\end{array}$} & \multicolumn{3}{|c|}{ Total Convictions } & \multicolumn{3}{|c|}{ Convictions per Man } \\
\hline & & Murder & Assault & $\begin{array}{c}\text { Sexual } \\
\text { Assault }\end{array}$ & Murder & Assault & $\begin{array}{l}\text { Sexual } \\
\text { Assault }\end{array}$ \\
\hline $\begin{array}{l}\mathbf{X Y Y} \\
\mathbf{X Y}\end{array}$ & $\begin{array}{r}9 \\
18\end{array}$ & $\frac{1}{3}$ & $\begin{array}{r}22 \\
22\end{array}$ & $\begin{array}{r}5 \\
22\end{array}$ & $\begin{array}{l}0.1 \\
0.15\end{array}$ & $\begin{array}{l}0.2 \\
1 \cdot 2\end{array}$ & $\begin{array}{l}0.5 \\
1.2\end{array}$ \\
\hline
\end{tabular}

Table VI.-Records of Conviction Against Property (In Detail)

\begin{tabular}{|c|c|c|c|c|c|c|c|}
\hline \multirow[b]{2}{*}{ Category } & \multirow{2}{*}{$\begin{array}{l}\text { Total } \\
\text { Men }\end{array}$} & \multicolumn{3}{|c|}{ Total Convictions } & \multicolumn{3}{|c|}{ Convictions per Man } \\
\hline & & Theft & $\begin{array}{c}\text { House- } \\
\text { breaking }\end{array}$ & Others & Theft & $\begin{array}{c}\text { House- } \\
\text { breaking }\end{array}$ & Others \\
\hline$\underset{X Y Y}{X Y Y}$ & $\begin{array}{r}9 \\
18\end{array}$ & $\begin{array}{l}25 \\
51\end{array}$ & $\begin{array}{l}51 \\
74\end{array}$ & $\begin{array}{l}5 \\
7\end{array}$ & $\begin{array}{l}2 \cdot 8 \\
2 \cdot 8\end{array}$ & $\begin{array}{l}5 \cdot 8 \\
4 \cdot 1\end{array}$ & $\begin{array}{l}0.6 \\
0.4\end{array}$ \\
\hline
\end{tabular}

with another for strangling a fellow patient at an institution for the mentally subnormal.

\section{Previous Places of Detention}

Six of the nine XYY patients had been committed by the courts to institutions for the mentally subnormal, compared with only three of the 18 control patients. There was also a higher incidence of committal to approved schools, Borstals, and prisons among the XYY males. One of the XYY males and one of the control patients had previously been committed to a hospital for the mentally ill.

Transfer from an institution for the mentally subnormal was effected one to ten years after first admission to these hospitals. The reasons given for transfer included violence against the staff, threatened violence, or frequent absconding.

\section{Family Background}

The only instance of a severely disturbed family background among the XYY males was that of a father who, as a result of alcohol, was unable to keep steady employment and who was TABLE VII.-Family History of Criminal Convictions in 9 XYY Males

\begin{tabular}{|c|c|c|c|c|c|c|c|}
\hline & & & & & & $9 \mathrm{XYY}$ & 18 Controls \\
\hline \multicolumn{3}{|c|}{$\begin{array}{l}\text { No. of parents convicted of crime... } \\
\text { No. of convictions .. }\end{array}$} & $\because$. & $\because$. & $\ddot{x}$ & $\begin{array}{l}0 \\
0 \\
0\end{array}$ & 1 \\
\hline $\begin{array}{l}\text { No. of sibs } . \\
\text { No. of sibs convicted } \\
\text { No. of convictions } \ldots\end{array}$ & $\because$ & $\because$. & $\ddot{0}$ & $\because \ddot{x}$ & $\begin{array}{l}. . \\
. .\end{array}$ & $\begin{array}{r}31 \\
1 \\
1\end{array}$ & $\begin{array}{r}63 \\
12 \\
139\end{array}$ \\
\hline \multicolumn{3}{|c|}{ No. of families with criminal records* } & .. & .. &.. & 1 & 7 \\
\hline
\end{tabular}


often away from home for long periods. Most social classes are represented by these families; on the Registrar-General's classification two can be placed in class I, two in each of classes III and IV, and three in class V. None of the parents had a criminal record or history of mental illness (Table VII). Of 31 brothers and sisters, only one had a conviction, for the theft of $£ 5$ from an employer. This same brother had a history of mental illness-a reactive depression requiring hospital treatment for a very short period. No other members of their immediate families are known to have a history of mental illhealth.

As the families of the control patients have not been visited, the only reliable data available are the familial incidence of criminal offences. Of 36 parents, only one had a criminal record, but of 63 brothers and sisters 13 had criminal records. They were members of seven families and between them they had been convicted on 139 occasions. These convictions were fairly evenly distributed among the 13 offenders.

\section{Discussion}

The nine XYY male patients described suffered from a mental disorder: This abnormality had been diagnosed as a severe personality disorder for which there was no recognized cause. In an earlier communication (Price et al., 1966) mention was made of one patient in the group who showed some schizophrenic-like features. It is now thought that none of these patients suffered from a true psychosis.

Seven of the nine XYY patients were regarded as mentally subnormal, and six had previously been detained, sometimes for many years, at hospitals for the mentally subnormal. It is reasonable, therefore, to question what part mental subnormality may play in their disturbed behaviour, and it is probably relevant that these patients had been diagnosed as mentally subnormal after referral by the police and the courts and not, as with the great majority of the mentally subnormal, by education or health authorities (Hilliard and Kirman, 1965). It is clear that each one of the XYY patients had suffered from a severe disturbance of his whole personality and also that in none was intellectual function, at any level, sufficiently adequate to suppress the disordered drives leading to criminal behaviour. In considering all aspects of their behaviour as a group we have found no reason to implicate any particular aspect of personality. In most or all of these patients intellectual capacity, sexual instincts, aggressive impulses, and emotional responses all showed evidence of immaturity, defective development, or inadequate control.

There is no reason to believe that these patients would have indulged in crime had it not been for their abnormal personalities. There is no predisposing family environment, and their criminal activities often start at an age before they are seriously influenced by factors from outside the homes.

Moreover, repeated and prolonged attempts at corrective training and treatment have been unsuccessful. In spite of his persistent criminal behaviour the XYY male differs in many ways from the hardened criminal. He has, for example, little skill in crime, and his gains are small. There are, however, some features in common with the recidivist prisoners, of whom West (1963) describes the great majority to be " severely deviant in personality, and apparently unable to respond normally to other people or to function adequately in the roles expected of responsible adults," It is interesting to note that these recidivist prisoners also come from stable homes, but unlike the XYY males the average age at first conviction was 18 years.

All the data we have obtained from the examination of XYY males at the State Hospital at Carstairs lead us to believe that the extra $\mathrm{Y}$ chromosome has resulted in a severely disordered personality, and that this disorder has led these men into conflict with the law. It is as well to remember, however, that the men we have described may represent a selected group of XYY males, and that others found in the ordinary population, or even in penal populations, may show different features from those described above.

\section{Summary}

The behaviour of nine male patients with an XYY sex chromosome complement has been analysed and assessed.

It was found that (a) they suffered from a severe disorder of personality, in most instances associated with intellectual impairment, which it is suggested is due to the extra $Y$ chromosome; $(b)$ in their criminal behaviour they displayed less violence against persons than did control patients ; $(c)$ they began their criminal activities at a very young age, on average five years earlier than other patients at the hospital ; $(d)$ they had no significant family history of crime or mental illness; and (e) their criminal behaviour had proved in the past to be resistant to conventional forms of corrective training and treatment.

The significance of these findings is briefly discussed.

We wish to acknowledge the advice and assistance of Dr. R. P Brittain with the assessment of these patients. We are grateful to Dr. W. M. Court Brown for his help and encouragement, and to Mr. Peter Smith for statistical advice.

\section{REFERENCES}

Casey, M. D., et al. (1966a). Lancet, 2, 859.

Segall, L J., Street, D. R. K., and Blank, C. E. (1966b). Nature (Lond.), 209, 641.

Hilliard, L. T., and Kirman, B. H. (1965). Mental Deficiency, 2nd ed. London.

Jacobs, P. A., Brunton. M., Melville, M. M., Brittain, R. P., and McClemont, W. F. (1965). Nature (Lond.), 208, 1351.

Maclean, N., Harnden, D. G., Court Brown, W. M., Bond, J., and Mantle, D J. (1964). Lancet, 1, 286.

- et al. (1962). Ibid., 1, 293.

Price, W. H., Strong, J. A., Whatmore, P. B., and McClemont, W. P.

West, D. J. (1963). The Habitual Prisoner. London. 